\title{
Musik Internal dan Eksternal dalam Kesenian Randai
}

\author{
Sri Rustiyanti ${ }^{1}$ \\ Fakultas Seni Pertunjukan, Institut Seni Budaya Indonesia (ISBI) Bandung
}

\begin{abstract}
ABSTRAK
Kehidupan musik pada masyarakat Minangkabau tidak terlepas adanya peranan serta fungsi yang melekat pada kesenian Randai. Melalui pendekatan etnomusikologi, tulisan ini menelaah peranan musik internal dan eksternal dalam kesenian Randai. Kesenian ini menggunakan medium seni ganda atau kolektif karena didukung oleh beberapa cabang seni antara lain tari, musik, teater, sastra, dan rupa. Hasil penelitian menunjukkan bahwa musik iringan dalam Randai terbagi menjadi dua, yaitu musik internal dan musik eksternal. Musik internal adalah musik atau bunyi-bunyian yang berasal dari anggota tubuh manusia (penari), misalnya tepukan tangan, petik jari, tepuk dada, siulan, hentakan kaki ke tanah dan sebagainya, sedangkan musik eksternal adalah bunyi-bunyian atau suara yang berasal dari alat musik atau instrumen seperti talempong, gandang, saluang, dan rabab.
\end{abstract}

Kata kunci: musik internal, musik eksternal, Randai, Minangkabau

\begin{abstract}
The Role of Internal and External Music in the Arts of Randai. The musical life in Minangkabau society is inseparable from its roles and functions which attach to the arts of Randai. Through the ethnomusicology approach, this paper examines the role of internal and external music in the art of Randai. Considering its sustainability and amendment, the musicality is the identity of Minangkabau society so that the sustainability of the music can be run in accordance with the dynamics of society today. Among the types of arts in Minangkabau, Randai is an art form that uses multiple or collective art medium for it is supported by several branches of the arts, including dance, music, theater arts, literary arts, and fine arts. The results of this study is more focused on the art of music. Musical accompaniment in Randai is divided into two, namely internal and external music. The internal music is the music or the sounds that come from the human body (a dancer), for example, clapping, finger picking, patting the chest, whistling, stomping on the ground, and so on, while the external music is the sounds emanating from the tools of music or instruments, such as talempong, gandang, saluang, and rabab.
\end{abstract}

Keywords: internal music, external music, Randai, Minangkabau

\section{Pendahuluan}

Permainan anak nagari atau juga dikenal sebagai kesenian rakyat dalam bentuk musik dapat dikelompokkan menjadi dua yaitu (1) kelompok vokal/dendang yang disebut musik internal, dan (2) kelompok instrumental/karawitan yang disebut musik eksternal (Kartomi, 1990). Pada dasarnya Randai dapat diiringi alat-alat musik tradisional atau tidak sama sekali. Kesenian Randai dapat diiringi hanya musik internal saja, dibangun oleh penari galombang randai yang merupakan gerak bercirikan pencak silat dan selalu dilakukan dalam pola lantai tunggal, yaitu lingkaran dari awal sampai akhir pertunjukan Randai. Bentuk gerak galombang randai ini tampak jelas yang selalu dilakukan dalam lingkaran gerakan pencak dengan langkah maju atau mundur, ke dalam memperkecil lingkaran, atau sebaliknya ke luar membuat lingkaran lebih besar. Dengan bentuk lingkaran ini, setiap pemain merasakan persamaan dan kebersamaan dalam kelompok tanpa ada batas antara pemain yang satu dengan pemain yang lain.

Kesenian Randai sebagai salah satu warisan

\footnotetext{
Alamat korespondensi: : Jurusan Seni Tari, Fakultas Seni Pertunjukan, ISBI Bandung. Jln. Buah Batu no.212 Bandung. Hp: 081221418454. Email: rustiyantisri@yahoo.com
} 
tradisi budaya Minangkabau berkaitan dengan seni bunyi-bunyian dan dendang hingga kini masih terlihat eksis. Keberadaannya tidak saja didukung oleh masyarakat Minangkabau yang berdomisili di wilayah Sumatra Barat saja, tetapi termasuk wilayah persebaran sampai menembus batas-batas wilayah etnografinya. Dengan perkataan lain, kesenian Randai dapat hidup dan berkembang di luar wilayah budaya Minangkabau, bahkan di negara atau benua lain dengan masyarakat pendukungnya masing-masing.

Perkembangan seni tradisi Minangkabau berjalan tidak sepesat seperti di Jawa. Hal ini disebabkan karena macetnya upaya-upaya pelestarian yang seharusnya dilakukan oleh berbagai pihak yang berkompeten (Julius, 2007: 25). Walaupun demikian, kondisi ini tidak berarti bahwa upaya pelestarian kesenian tradisi itu tidak ada sama sekali. Beberapa pihak telah melakukan berbagai upaya, seperti memberikan idiom-idiom baru terhadap kesenian tradisi supaya lebih dapat dicerna dan diterima masyarakat generasi sekarang. Salah satu kesenian tradisi yang sudah mendapat kesempatan dikembangkan dengan kreasi baru adalah kesenian Randai, yang dikenal tidak hanya sebagai pamenan anak nagari (kesenian rakyat), tetapi juga dikenal sebagai seni pertunjukan.

Pendukung musik Randai, terbagi menjadi dua bagian, yaitu musik internal dan musik eksternal. Musik internal yaitu musik yang dilahirkan atau dibangun oleh penari (anggota tubuh manusia), seperti bunyi dari tapuak galembong (tepuk pada celana yang mempunyai pisak yang lebar), tepuk tangan, tepuk paha, tepuk kaki, tepuk siku, petik jari, dan hentakan kaki. Bunyi tersebut dapat menghasilkan tempo, dinamika, dan ritme yang menarik dan atraktif. Adapun musik eksternal yaitu alat-alat musik tradisional Minangkabau, seperti saluang, bansi, talempong, dan gandang. Kehadiran bunyi musik tradisional memang tidak mutlak meskipun cukup penting sebagai pemberi semangat dalam galombang randai, sehingga menjadi lebih hidup dan bergairah. Selain difungsikan untuk mengiringi gerak galombang, juga berperan untuk membuka dan menutup acara pertunjukan Randai. Alat musik pemanggil dalam pertunjukan Randai sebagai pemberitahu bahwa akan diadakan pertunjukan Randai di suatu tempat. Pemain musik tersebut terdiri atas seorang peniup sarunai, tiga orang pemukul talempong, dan sepuluh orang pemukul tambur (masing-masing pemukul tambur membawa sebuah tambur yang mempunyai ukuran yang berbeda-beda).

Sebagai seni sastra, Randai adalah cerita yang unik, ia bukan saja untuk dibaca, melainkan untuk dipertunjukkan sebagai tontonan. Salah satu bentuk sastra Minangkabau yang paling populer yaitu pantun. Pantun sering digunakan untuk percakapan dalam cerita Randai, percakapan sehari-hari, hiasan berpidato, dalam dendang, dan sebagainya. Pantun dalam Randai terdiri atas beberapa baris dengan jumlah selalu genap. Baris pertama dari permulaan merupakan sampiran dan bagian baris berikutnya adalah isi pantun yang sebenarnya. Bentuk pantun bermacam-macam, ada yang hanya terdiri atas dua baris, ada pula yang terdiri atas enam sampai dua belas baris. Irama alunan dendang dalam Randai pada umumnya berbentuk pantun, syair, talibun, seloka, dan prosa liris, yang secara keseluruhan disebut dengan istilah gurindam randai. Kelima bentuk gurindam tersebut dipakai dalam dendang Randai sebagai musik internal yang dilakukan oleh pendendang dan penari galombang randai. Dendang yang mempunyai irama melodi yang panjang, gurindamnya biasanya berbentuk talibun, yaitu sejenis pantun yang mempunyai baris lebih dari empat. Kalau isi dendang mengisahkan suatu cerita adegan, maka gurindamnya berbentuk prosa liris, karena bentuk gurindam ini tidak terikat oleh baris dan sajak bunyi tiap-tiap baris. Dengan demikian, penggunaan bentuk gurindam disesuaikan menurut jenis dendang yang digunakan.

Ada permasalahan yang menarik untuk dicari jawabannya dalam tulisan ini, yaitu: (1) bagaimana peranan musik internal dan eksternal dalam kesenian Randai pada masyarakat pendukungnya, (2) mengapa masyarakat Minangkabau masih mendukung kesenian Randai, dan (3) faktorfaktor apa saja yang mempengaruhi terhadap keberlangsungan dan perubahan musik dalam kesenian Randai. Untuk menjawab permasalahan ini, konsep musik sebagai kebudayaan dan hubungan dengan studi musik dan budaya tulisan Merriam (1964: 32) dapat menuntun dalam 
melihat permasalahan tersebut. Menurutnya, setiap sistem musik didasarkan atas serangkaian konsep-konsep yang berhubungan dengan aktivitas masyarakat serta menempatkannya pada fenomena kehidupan.

\section{Peralatan Alat Musik dalam Randai}

Peranan alat musik dalam kesenian Randai pada hakikatnya adalah sebuah komposisi bunyi yang cukup sederhana dengan strukturnya, dan tidak semua alat musik dapat sesuai dan dipakai sebagai musik pengiring Randai. Kalau diamati hubungan gerak dan musik pada kesenian Randai, maka musik berperan sebagai berikut: 1) sebagai partner galombang randai (tari), yaitu memberikan pola-pola ritme dan melodi yang sesuai dengan tuntutan irama gerak galombang; 2) sebagai latar belakang gerak tokoh lakon cerita Randai; 3) memberikan ilustrasi suasana adegan sesuai dengan aspek-aspek dramatis yang terdapat dalam cerita Randai.

Musik seringkali diciptakan untuk memenuhi kebutuhan dramatis panggung, artinya sebagai pelengkap emosional untuk saat-saat penting dalam sebuah karakter lakon cerita Randai. Jika ada musik yang mengiringi dialog, maka terlebih dahulu pemain musik harus mengetahui kecepatan pengucapan dialog naskah Randai, keheningan gerakan-gerakan yang akan dipakai, sehingga musik dapat sesuai sampai ke hal-hal yang detail dengan pementasan tersebut. Apabila musik tidak sesuai dengan detail adegan cerita Randai, maka efek musiknya mungkin akan bertentangan atau ditempatkan pada posisi yang salah.

Secara musikal penggarapan alat-alat musik dalam Randai, terdapat tiga cara yaitu: (1) Menghitung jumlah ketukan pada setiap pengulangan, perubahan gerak galombang, atau dapat juga dengan mengambil musik yang telah ada kemudian mencocokkan dengan jumlah ketukan gerak galombang tersebut; (2) Gerak galombang yang tidak mempunyai ritme (ritme bebas) yang tidak dapat ditentukan ketukannya, dapat diiringi dengan dendang yang tidak mempunyai ritme pula, seperti pada dendang Banda Sapuluah/Palayaran (dendang yang bersifat ratok/ratap); (3) Apabila terjadi perubahan baik pada gerak galombang maupun gerak musik, harus dengan memberi kode-kode tertentu. Kadang-kadang antara musik dan gerak bersifat kontras, maksudnya gerak yang mempunyai ketukan teratur/terikat diiringi dengan musik yang ketukannya bebas atau sebaliknya.

Berdasarkan teori fungsi menurut Merriam (1964: 219-227) membagi fungsi musik dalam berbagai peranan musik dapat diterapkan pada kehidupan masyarakat, dan mempunyai nilai fungsi yang dibuat dapat berlaku secara universal. Dirumuskan sepuluh macam fungsi musik dalam masyarakat yaitu sebagai: (1) ekspresi emosional, (2) kenikmatan estetik, (3) hiburan, (4) komunikasi, (5) representasi simbolis, (6) reaksi jasmani, (7) memperkuat penyesuaian dengan norma-norma sosial, (8) pengesahan institusi sosial dan ritual agama, (9) sumbangan pada pelestarian dan stabilitas kebudayaan, dan (10) sumbangan bagi integritas sosial.

Oleh karena berbagai kepentingan dan tuntutan yang terjadi dalam masyarakat terhadap penggunaan musik, maka berdampak pula kepada fungsinya, sehingga fungsi musik pun menjadi bertambah. Berdasarkan perumusan fungsi tersebut dan dikaitkan dengan kesenian Randai, fungsinya dapat dilihat berdasarkan pemahaman yang terkonsepsi dalam masyarakat Minangkabau, baik melalui pemusiknya maupun masyarakat sebagai penyelenggara, atau melalui sebuah pengamatan. Musik tradisional sangat lazim digunakan sebagai suatu bentuk ekspresi masyarakat. Musik ini banyak digunakan dalam kegiatan rakyat biasa sehingga bersifat lebih sederhana dan santai.

Demikian pula masyarakat Minangkabau, walaupun mereka hidup di luar lingkungan budaya Minang, tetapi konsep yang ada di alam pikiran masih mengacu kepada induk budayanya, bahkan ingin mempertahankanya di tempat di mana hi-dup. Aktivitas seni pertunjukan musik merupakan fenomena sosial budaya bagi masyarakat pendukungnya tidak hanya untuk memuaskan kebutuhan individual, tetapi justru untuk mempertahankan struktur sosial masyarakatnya. Sangat disadari, bahwa selain berbagai ragam status (identitas) sosial masyarakat Minangkabau dapat diasumsikan masih memiliki kebiasaan dalam 
melaksanakan berbagai cara tradisi Minangkabau yang dibangun dan dibawa oleh leluhurnya untuk melestarikannya. Pelestarian tersebut hingga menembus batas-batas etnis, sehingga segala bentuk atau nilai-nilai tradisi Minangkabau di mana pun masyarakat itu berada, secara sadar mereka akan berupaya dan mengupayakan untuk melestarikannya, sesuai dengan situasi dan kondisi masyarakat bersangkutan. Seperti, pada kehidupan kesenian Randai sebagai salah satu jenis pamenan anak nagari yang didukung oleh musik internal dan musik eksternal, dapat mempertegas identitas sosial masyarakat Minangkabau yang hidup di tengah-tengah masyarakat global (Merriam,1964: 219-226).

Dalam masyarakat, menakar identitas dapat dipantau melalui tiga bentuk, yaitu identitas budaya, identitas sosial, dan identitas pribadi (Liliweri, 2002: 95). Identitas budaya muncul karena seseorang itu merupakan anggota dari sebuah kelompok etnik tertentu, sedangkan identitas pribadi lebih berdasarkan pada keunikan karakteristik pribadi seseorang. Berkaitan dengan upaya mempertegas identitas sosial, tentu saja masyarakat Minangkabau yang berdomisili di luar wilayah budayanya, termasuk sebagai masyarakat perantau selain berusaha untuk dapat diterima sebagai anggota masyarakat pada umumnya dalam saling berinteraksi, juga masih memiliki ingatan kolektif atau pikiran kolektif (Koentjaraningrat, 1990: 210-211) yang berwujud konsep dan khasanah budaya bagi masyarakat pendukungnya. Oleh karena itu, di mana pun, kapan pun, dan bagaimana pun, sampai sekarang masyarakat tersebut sebagian besar masih tetap mempertahankan bahasa dan adat istiadat mereka (Suseno, 1999: 11).

Pertunjukan kesenian Randai kaitannya dengan penyelenggaraan upacara adat atau upacara ritual lainnya merupakan kegiatan penting. Hal ini secara tidak langsung dapat memberikan kepuasan atau pemenuhan akan rasa musikal serta ungkapan estetis terhadap masyarakat pendukungnya; di samping merupakan salah satu kebutuhan hidup manusia pada umumnya setelah kebutuhan pokok terpenuhi (Boas,1995: 9). Selain memiliki nilai sosial untuk saling berinteraksi, berkaitan dengan rasa keidentitasan dalam keberagaman budaya, juga dapat mengembangkan seni budaya khususnya kesenian Randai.

\section{Musik Eksternal Pendukung Randai}

Musik eksternal pendukung Randai berupa alat-alat musik tradisional Minangkabau, seperti saluang, bansi, talempong, canang, gandang, dan rabab. Kehadiran alat musik dalam mengiringi Randai selalu dikaitkan dengan alek nagari, upacara keadatan atau acara lainnya yang diselenggarakan oleh masyarakat Minangkabu. Musik talempong bukan merupakan sesuatu yang sifatnya harus selalu ada dalam setiap pertunjukan Randai yang diadakan di tengah masyarakat. Namun, eksistensinya di tengah berbagai pamenan anak nagari (permainan rakyat) tersebut selalu memberikan identitas pada masyarakat sebagai tanda adanya alek nagari (keramaian pesta rakyat). Dalam penyajiannya, alat musik talempong dapat terdiri atas beberapa alat musik pendukung, seperti: gandang, saluang, rabab, canang, bansi, dan alat musik lainnya. Namun dalam permainan talempong kreasi, tidaklah mutlak alat musik yang digunakan ialah alat musik tradisional Minangkabau. Ada kalanya kreasi yang tampil dikombinasikan baik dengan alat musik daerah lain di Indonesia maupun alat-alat musik Barat, seperti: gitar, biola, saksofone, klarinet, flute, dan keyboard.

Talempong memiliki bentuk dan nama yang beraneka ragam. Nama dan bentuk alat musik tersebut sering disesuaikan dengan bahan baku yang dipakai pada proses pembuatannya, nama daerah asal alat musik, jumlah talempongyang digunakan, posisi alat saat dimainkan, serta penggunaannya. Hal ini dapat dilihat dari beberapa nama yang diberikan pada alat musik tersebut, seperti talempong batu di daerah Talang Anau Kabupaten 50 Kota yang terbuat dari batu, talempong batuang di nagari Sungai Talang Kabupaten 50 Kota yang terbuat dari batuang (bambu), talempong aguang yang dipakai untuk upacara-upacara adat yang penuh dengan berbagai kebesaran (agung), talempong pacik yang dimainkan dengan dipacik (dipegang) dan talempong kreasi yang merupakan musik sebagai hasil kreativitas orang yang memainkannya. 
Talempong di Minangkabau dapat dibedakan menjadi dua macam. Pertama, Talempong Pacik (yang dipegang) dan kedua, Talempong Real yang diletakkan di atas rancakan. Talempong Pacik dapat dimainkan sambil duduk, berdiri, dan berjalan; sedangkan Talempong Real mempunyai dua model real (rancakan), yaitu berukuran rendah sehingga dapat dimainkan sambil duduk di atas tikar dan berukuran tinggi yang dapat dimainkan sambil berdiri atau duduk di kursi. Gandang yang digunakan pada musik talempong kreasi sebanyak dua buah, namun hal ini tidak mutlak harus dua buah. Dapat saja dalam sebuah pertunjukan menggunakan satu gandang atau lebih dari dua gandang, ini disesuaikan dengan kondisi di lapangan dan kebutuhan. Gandang 1 berfungsi sebagai alat musik pengatur tempo gerak galombang. Perjalanan motifnya diusahakan teratur dengan sedikit variasi untuk bagian-bagian tertentu dari lagu yang sifatnya menguatkan momen tertentu pada sebuah iringan musik. Gandang 2 berfungsi sebagai gandang paningkah dan memberikan improvisasi pada bagian-bagian tertentu dari iringan musik, seperti pada singkop-singkop dan rovel-rovel. Dalam permainan gandang, improvisasi pemain dalam menghidupkan suasana, sehingga memiliki pengaruh yang besar terhadap pertunjukan secara keseluruhan.

\section{Musik Internal Pendukung Randai}

Musik internal, yaitu musik yang dibangun oleh penari itu sendiri yang menghasilkan ritme bunyi dari tubuh penari, seperti vokal, tepuk tangan, petik jari, siulan, hentakan kaki, dan sebagainya. Musik internal dikembangkan berdasarkan hasil eksperimen penari. Misalnya eksperimen terhadap bunyi yang berasal dari mulut didasarkan pada eksplorasi pada sumber bunyi tersebut. Eksplorasi merupakan salah satu cara penting yang dilakukan komponis dalam membuat sebuah komposisi, karena eksplorasi menjadi penunjang ide kreatif (Dewi, 2013: 110).

Salah satu bentuk vokal yang cukup populer di Minangkabau yaitu dendang yang berirama gembira dan ratok (ratap) yang berirama sedih. Penting sebagai pendendang mengalami, mempelajari, dan merasakan perbedaan karakteristik dendang dan ratok. Seperti halnya dalam gamelan laras slendro lebih cocok untuk mengiringi tari-tarian yang bersifat gembira, terbuka, dan meriah. Sebaliknya tarian bedaya yang anggun, agung, dan berwibawa lebih memilih diiringi gending yang berlaras pelog (Daruni, 2013: 167). Dengan demikian tujuan untuk memberikan baik jiwa tari maupun dendang sesuai dengan suasana karakteristik yang diinginkan.

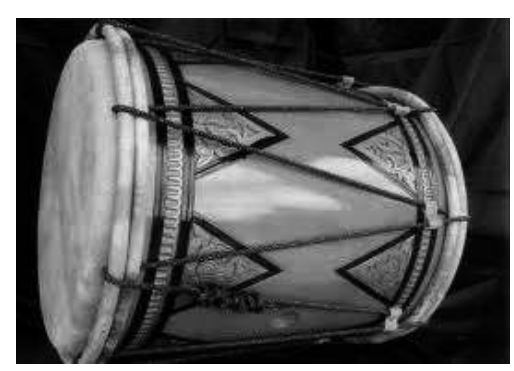

Alat musik pukul gandang

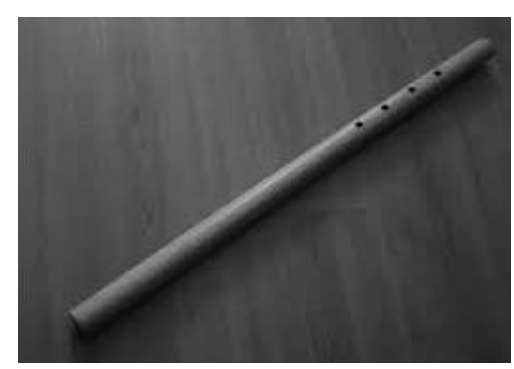

Alat musik tiup saluang

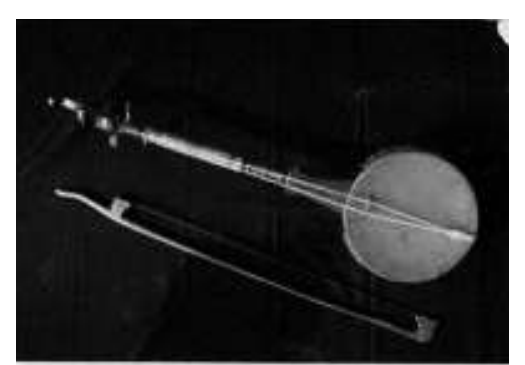

Alat musik gesek rabab

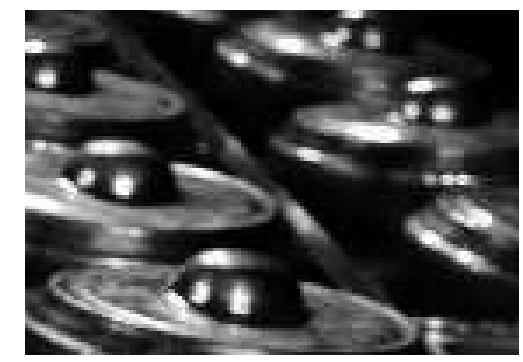

Alat musik pukul talempong

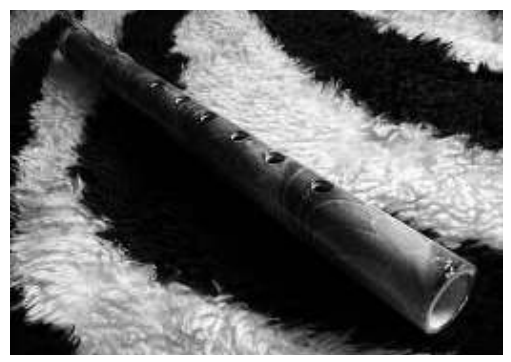

Alat musik tiup bansi

Gambar 1. Musik eksternal Minangkabau (Foto: Rustiyanti, 2014) 
Dendang berarti lagu, berdendang berarti bernyanyi. Dendang termasuk salah satu seni musik tradisi Minangkabau yang berbentuk vokal atau suara yang dihasilkan oleh manusia. Dendang adalah suara yang dilagukan manusia dan sangat berfungsi dalam pelaksanaan sebuah cerita Randai. Suara dendang itu untuk memberi batas peralihan dari adegan satu ke adegan berikutnya dan untuk menjelaskan jalan cerita yang tidak begitu penting untuk didialogkan antara para tokoh lakon cerita, sehingga dengan dendang jalan cerita tidak terputus dan dapat diikuti melalui syair dendang yang dinyanyikan oleh pendendang. Namun ada juga pendapat lain yang mengatakan bahwa kehadiran dendang dalam Randai berfungsi sebagai pengatur cerita dari satu adegan ke adegan berikutnya.

Jenis dendang yang digunakan dalam Randai tergantung dari jumlah legaran atau adegan cerita Randai. Sekarang sudah menjadi kesepakatan bagi seluruh seniman, bahwa dendang yang digunakan akan selalu dimulai dengan dendang Dayang Daini sebagai dendang persembahan, kemudian dilanjutkan dendang Simarantang untuk legaran atau adegan pertama. Dendang untuk legaranlegaran di tengah menggunakan dendang bebas sesuai menurut suasana cerita itu sendiri, dan legaran terakhir menggunakan dendang Palayaran. Bentuk penampilan dendang dalam Randai dimaksudkan untuk menyampaikan sesuatu, misalnya menyampaikan keadaan dalam perjalanan, perpindahan legaran, dan mengatur langkah gerak. Selain pendendang yang mengalunkan dendang yang dibawakannya, mereka juga diikuti oleh anak randai atau penari galombang pada setiap baris akhir dendang secara bersama-sama. Dendang dalam Randai tidak selalu dibarengi dengan karawitan karena untuk pengatur gerak langkah dapat diiringi dengan dendang saja.

Secara umum, dendang dapat dibagi menjadi dua jenis, yaitu dendang ratok dan dendang gembira. Dilihat dari bentuk melodinya, dendang ratok termasuk dendang yang berirama bebas, sedangkan apabila dilihat dari unsur syair atau isi pantunnya, dendang ratok berisi ungkapan perasaan yang gundah dan sedih, yang meratapi nasib sambil berdendang. Dendang gembira merupakan ungkapan kegembiraan. Syair atau pantun-pantun yang dilantunkan umumnya berisi ungkapan sukacita. Jenis dendang yang digunakan dalam Randai tergantung dari jumlah legaran cerita yang dibawakan.

Berikut ini adalah peranan dendang dalam Randai: (a) Dendang pasambahan. Sebagai penghormatan kepada penonton, pasambahan mengawali setiap pertunjukan dimaksudkan untuk meminta keridhoan Tuhan Yang Maha Esa, juga menghaturkan maaf kepada para penonton. Dendang pasambahan diambil dari dendang ratok yaitu Dendang Dayang Daini; (b) Dendang pengatur adegan. Sebelum akting dan dialog legaran pertama dimulai, didahului dengan sebuah dendang yaitu Dendang Simarantang yang merupakan dendang untuk memulai legaran pertama, sehingga dialog dan akting pada masing-masing legaran dapat dilakukan setelah diantarkan oleh sebuah dendang. Setelah dendang berakhir, ditutup dengan ' $h e p-t a$ ' (kata seru dalam Randai) dan tapuak galembong; (c) Dendang sebagai penentuan tempat. Semua peristiwa dan kejadian dalam cerita dapat diketahui dan dimengerti melalui dendang, seperti dalam salah satu cerita yang lain ketika si tokoh pergi merantau, kisah perjalanannya didendangkan dengan Ratok Lawang yang disebut juga dendang penentuan tempat; (d) Dendang sebagai penyampaian cerita. Peristiwa dan kejadian yang disampaiakan melalui dendang, sebagai contoh dalam Cindua Mato, cerita ini diangkat oleh kelompok Koto Singgalang Padang Panjang, dengan kisah Puti Bungsu dan anak Bundo Kanduang. Kisah dalam cerita ini tidak disampaikan dalam dialog, tetapi dengan dendang; (e) Dendang sebagai penentuan suasana. Cerita diangkat dari Kaba, peristiwa, dan kejadian dalam kehidupan masyarakat setempat. Menurut Harymawan dalam bukunya Dramaturgi bahwa peristiwa dan kejadian dalam cerita ada dua bentuk yaitu tragedi (cerita duka) dan komedi (cerita suka). Cerita yang disajikan berbentuk tragedi, maka dendang yang dibawakan jenis Dendang Ratok (ratap), sebaliknya cerita komedi dengan suasana gembira, maka dendang yang dibawakan bersifat ritmis dan riang; (f) Dendang sebagai penutup cerita. Dalam komposisi karawitan bila gending akan berhenti, maka selalu ada tanda henti yang harus dilakukan oleh pengendang pada lagu kalimat tertentu. 
Akan tetapi dalam penyajian, hal tersebut dapat diketahui melalui dendang penutup cerita yaitu Dendang Palayaran.

Dalam berdendang tidak ada aturan khusus seperti sistem notasi Barat, tangga nada solmisasi dan sistem accord. Memainkan dendang Minangkabau boleh dikatakan tidak ada sistem yang terdapat pada musik Barat yang merupakan aturan-aturan yang baku dan berlaku secara umum (Martamin, 1988: 13). Meskipun demikian, secara tradisional dendang Minangkabau mempunyai aturan tersendiri, hanya saja tidak dapat didefinisikan secara jelas seperti yang terdapat pada sistem notasi. Hal itu memungkinkan setiap pendendang mempunyai cara atau gaya tersendiri (kiek dan garinyiek) dalam berdendang, sehingga pelahiran dendang akan memberi warna khas bagi pendendang yang satu dengan pendendang yang lain. Kotska (2006: 176) menjelaskan bahwa terdapat beberapa ciri musik tanpa nada yang ditetapkan selain gaya tonal, yaitu musik tidak mempunyai pusat tonal. Aspek ini mempunyai sifat subjektif, bagi dua pendengar, mungkin berbeda pendapat mengenai sejauh mana pusat tonal yang boleh didengar di dalam sebuah karya musik tertentu (Batubara, 2013: 94).

Berikut adalah urutan teknis penyajian Randai:

1. Dengan aba-aba dari janang, seluruh pemain masuk ke dalam arena membentuk dua baris berbanjar dengan langkah silat membentuk lingkaran galombang. Pemain yang lain membalas kata "hep-ta" atau "ais-ta" dengan kata yang sama berulang-ulang sebanyak empat

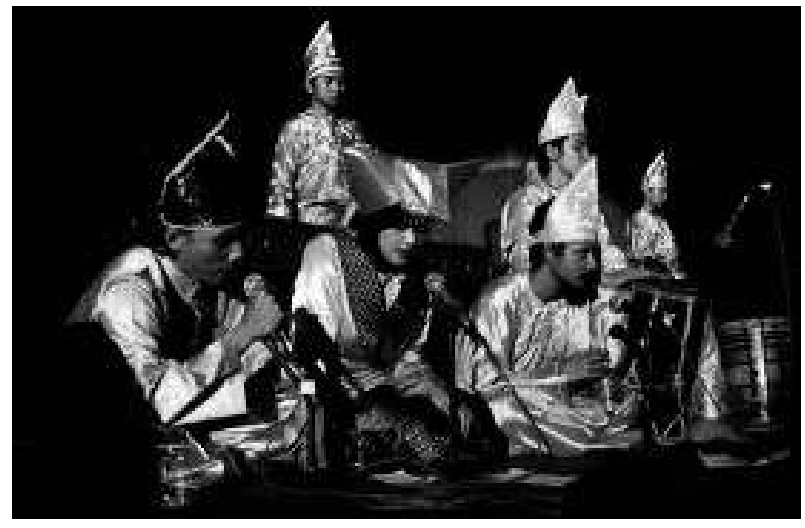

Gambar 2. Kelompok musik yang mengiringi gerak galombang dari Dendang Samarantang hingga Dendang Palayaran (Foto: Rustiyanti, 2014) kali secara bersama-sama. Sebelum pertunjukan dimulai, terlebih dahulu dimainkan alat-alat musik tradisi terdiri atas talempong, sarunai, bansi, dan gandang. Fungsi bunyi-bunyian ini sebagai pemanggil dan tanda adanya suatu acara tertentu. Memanggil masyarakat (penonton) merupakan suatu acara pertama sebelum pertunjukan dimulai.

2. Setelah seluruh pemain siap berada dalam arena, salah seorang pemain berdiri di tengah arena. Pemain ini dinamakan janang yang fungsinya sebagai ketua.

3. Setelah itu, tukang goreh memberi kode " $h e p-t a$ ", maka seluruh anak randai duduk berjongkok. Kemudian pembawa gurindam mulai berdendang Dayang Daini sebagai dendang persembahan kepada seluruh penonton.

4. Setelah selesai dendang Dayang Daini, tukang goreh memberi kode untuk berdiri dan bergerak dalam lingkaran galombang pertama.

5. Salah seorang berdiri di tengah lingkaran galombang untuk menyampaikan kata-kata persembahan kepada penonton. Setelah persembahan selesai, tukang goreh memberi tanda dengan suara kode "hep-ta" untuk mengajak para pemain berdiri dengan bergaya silat. Kemudian dilanjutkan dengan gerak galombang berikutnya yang diiringi dengan Dendang Simarantang untuk adegan pertama.

6. Dendang Simarantang dinyanyikan beberapa kali, tergantung dengan panjangnya gerak galombang, kemudian dilanjutkan dengan tampilnya tokoh lakon cerita yang berakting di dalam arena lingkaran galombang. Begitulah

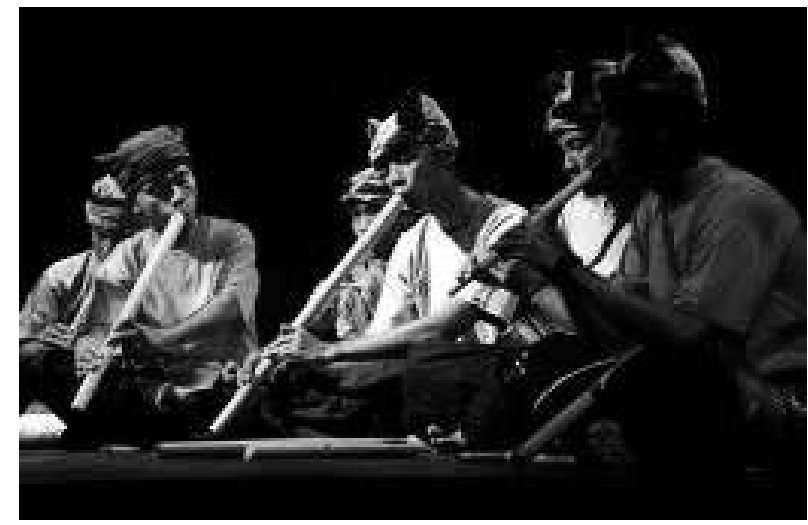

Gambar 3. Kelompok Saluang Dendang kadang-kadang sebagai selingan adegan galombang

(Foto: Rustiyanti, 2014) 
selanjutnya adegan demi adegan sampai legaran terakhir. Antara tokoh yang satu dengan yang lain bergantian menyampaikan dialog sesuai dengan naskah lakon.

7. Kadang-kadang dalam pertunjukan, pada waktu anak randai duduk melepoh (istirahat), tidak ditampilkan tokoh cerita tetapi diselingi dengan tarian perintang (variasi hiburan), seperti tari piring, pencak silat atau saluang dendang. Dengan selingan ini, perlu adanya variasi acara, sehingga akan lebih menggairahkan para penonton dari kejenuhan.

Syair dendang menggunakan bahasa daerah Minangkabau, begitu juga musik tradisional menggunakan alunan melodi dan irama yang menunjukkan ciri khas keminangannya. Misalnya, syair dendang lagu alunan melodinya menggunakan nada-nada dari tangga nada yang tersusun atas tangga-tangga nada diatonis. Musik tradisional merupakan salah satu bentuk kebudayaan yang berkembang di dalam kehidupan masyarakat. Oleh karena itu, setiap kebudayaan dengan masyarakat sebagai pendukung kebudayaan yang disangganya pasti sudah melekat erat di dalam sanubarinya. Musik daerah merupakan salah satu bentuk gambaran kebudayaan suatu daerah, selain tarian, pakaian, dan adat kebiasaan lainnya.

Melalui musik daerah dapat dikenali daerah asal musik itu dan ciri budaya masyarakatnya. Misalnya: ketika mendengarkan permainan talempong pacik langsung diketahui kalau itu adalah musik daerah Minang, atau bunyi gamelan itu dari Jawa Tengah, bukan dari Kalimantan. Maka dapat dikenalinya lewat karakter permainan talempong atau gamelan terutama lewat suara, irama, dan lagunya. Karakter inilah yang menggambarkan identitas dan ciri khas suatu daerah. Salah satu contohnya adalah irama musik gamelan Jawa yang umumnya terdengar melantun halus dan lembut. Hal ini menunjukkan budaya orang Jawa yang menekankan tutur kata yang halus, ramah, dan sopan. Dari pengertian dan ciri-ciri musik tradisional tersebut, dapat diambil kesimpulan bahwa musik tradisi cenderung bersifat eksklusif. Artinya, musik ini tidak dapat dinikmati secara luas oleh masyarakat di luar kebudayaan yang melahirkan musik tersebut.
Komposisi, fungsi, nilai, dan karakteristik syair musik tradisi suatu masyarakat sangatlah khas sehingga tidak mudah untuk dinikmati atau diterima sebagai bagian dari kebudayaan masyarakat lain. Oleh karena itu, musik tradisi cenderung kurang dapat berkembang sehingga musik ini sering disebut sebagai musik tradisional.

Analisis fungsi musik di dalam masyarakat merupakan sebuah pengkajian terhadap sebabsebab mengapa musik tersebut digunakan, sehingga dampak dari penyelenggaraan musik itu mencapai tujuannya yang paling utama. Dengan kata lain, apa yang diberikan musik untuk manusia, itulah fungsi musik bagi manusia. Pandangan tentang fungsi musik bagi masyarakat dikemukakan Soedarsono (2002), yang membagi fungsi musik pada masyarakat ada tiga macam, yaitu : 1) sebagai sarana upacara, 2) sebagai sarana hiburan pribadi, dan 3) sebagai sarana penyajian estetis. Berdasarkan pendapat tersebut, fungsi musik talempong kreasi di dalam masyarakat pendukungnya dapat dianalisis disesuaikan dengan maksud dan tujuan penyajiannya di tengah masyarakat. Talempong kreasi biasanya disajikan pada upacara penyambutan tamu, upacara batagak panghulu dan upacara pesta perkawinan. Dari upacara-upacara yang diselenggarakan tersebut, musik talempong kreasi memiliki makna dan fungsi tersendiri baik oleh pihak penyelenggara upacara maupun pihak yang menyaksikan upacara, dalam hal ini undangan, tamu, dan unsur masyarakat lainnya.

\section{Fungsi Musik Randai dalam Masyarakat Minang}

Fungsi ekspresi emosional lahir secara spontan dari dalam diri pemain Randai. Setiap manusia mempunyai ekspresi emosional yang berbeda-beda tergantung pada interpretasi terhadap sesuatu yang dilihatnya, untuk mengungkapkan rasa suka, duka, senang atau tidak senang, terharu, sedih, riang, dan gembira saat menyaksikan sajian kesenian Randai. Dengan diperdengarkannya baik musik internal maupun musik eksternal pengiring Randai, maka secara langsung atau pun tidak langsung akan menimbulkan atau membangkitkan emosional saat menyaksikan pertunjukan tersebut. Misalnya, saat dendang yang dibawakan dengan iringan 
musik ini bernuansa atau bertema parasaian, kegagalan, kekecewaan dan seterusnya, apabila secara spontan membawa dampak pada masyarakat untuk mengekspresikan emosionalnya, seperti: meneteskan air mata (sedih) dan terharu, maka dikatakan bahwa sajian dendang yang ditampilkan tersebut mempunyai fungsi ekspresi emosional. Hal ini sesuai dengan penjelasan bahwa musik dapat memenuhi fungsi yang pertama dari 10 fungsi musik bagi masyarakat (Merriam, 1987).

Fungsi komunikasi merupakan bagian terpenting dalam berinteraksi antar penonton dan tontonan Randai. Bentuknya disesuaikan dengan lingkungan dan peradaban setiap manusia. Komunikasi memberikan beberapa keuntungan, di antaranya dapat memperoleh ilmu dan informasi. Dengan demikian, komunikasi dapat dikatakan sebagai suatu proses pertukaran informasi antar individu melalui sistem lambang, tanda, dan tingkah laku. Pada pertunjukan musik Randai, tanda yang dapat ditangkap oleh masyarakat ialah bunyi-bunyian. Bunyi-bunyian dimaksud ialah bunyi instrumen musik yang diperdengarkan oleh musik eksternal. Tanda ini memberikan informasi kepada masyarakat, bahwa telah ada sebuah upacara adat yang melibatkan musik tradisional Minangkabau (Bahar, 2009: 252), misalnya: upacara pesta perkawinan dan upacara penyambutan tamu. Masyarakat akan memberikan respon dengan berkunjung baik untuk meramaikan dan menyaksikan upacara yang dilangsungkan oleh penyelenggara upacara maupun hanya untuk menyaksikan pertunjukan musik talempong kreasi. Di sini dapat diamati bahwa pada satu sisi penyelenggara upacara telah menggunakan musik misalnya talempong pacik sebagai media komunikasi dengan masyarakat tentang upacara yang sedang dilangsungkan, yang berarti pula bahwa talempong pacik telah memenuhi fungsi keempat dari fungsi musik (Merriam, 1987).

Fungsi reaksi jasmani ditimbulkan karena adanya aksi yang diterima oleh penonton Randai. Aksi di sini ialah sajian musik internal dan music eksternal dalam mengiringan gerak galombang randai. Dengan penyajian musik ini, baik secara langsung maupun tidak langsung akan merangsang atau memancing masyarakat atau orang yang menyaksikan pertunjukan Randai untuk bereaksi.
Reaksi tersebut dapat dalam berbagai bentuk, seperti reaksi dari sisi orang yang menyajikan pertunjukan Randai, yaitu jasmaninya ikut bergerak mengikuti tempo musik untuk mengekspresikan emosional dirinya memainkan musiknya. Selain dari itu, penonton yang banyak akan membuat para pemain musik akan tampil lebih bersemangat, sehingga kepuasan maksimum dapat tercapai, baik oleh orang yang menyajikan maupun yang menyaksikan pertunjukan Randai tersebut. Adapun reaksi orang yang menyaksikan penyajian Randai tersebut, dapat dilihat seperti ikut bergerak, menari atau bergoyang menyesuaikan gerak dengan irama yang didengarnya baik disadari ataupun tidak disadari. Fungsi musik keenam dari Merriam (1987) pun telah dipenuhi oleh musik tersebut.

Fungsi hiburan. Secara umum musik internal dan musik eksternal pengiring Randai dalam pertunjukannya berfungsi sebagai media hiburan bagi masyarakat. Demikian pula halnya dengan musik saluang, bansi, canang, gandang, dan rabab. Talempong kreasi adalah musik tradisional Minangkabau yang telah dimodifikasi baik dari sisi sistem tangga nada, maupun bentuk penyajian maupun alat-alat musik yang digunakan, walaupun instrumen musik pendukung utamanya tetap instrumen musik tradisi. Dalam penyajian musik pengiring Randai saat ini, beberapa alat musik tradisi sering dikombinasikan dengan musik yang sudah diprogram, yang dikenal dengan nama orgen tunggal. Musik orgen tunggal ini menggunakan keyboard tunggal sebagai alat musiknya, di mana telah tersedia bermacam-macam musik yang telah diprogram untuk kebutuhan pertunjukan musik secara umum dan bebas. Musik dalam sajian seperti inilah yang lebih banyak atau sering ditampilkan untuk berbagai bentuk kesenian Randai atau upacara keadatan yang diselenggarakan masyarakat. Begitu pula, dengan musik talempong kreasi dapat menyajikan lebih banyak pilihan lagu dan pilihan aliran musik, tentunya dalam bentuk yang telah termodifikasi. Hal ini menyebabkan semakin banyak musik pengiring Randai yang berkembang sesuai dengan selera masyarakat yang mampu atau dapat ditampilkan dengan iringan musik internal dan eksternal. Bagi orang yang menikmati musik tersebut akan timbul dorongan dari dalam dirinya 
untuk ikut berekspresi atau bereaksi. Di sini dapat dikatakan bahwa orang yang menyaksikan pertunjukan Randai tersebut telah terhibur oleh penyajian musik internal dan musik eksternal yang telah disajikan. Tingkat keterhiburan masyarakat menyaksikan pertunjukan musik memberikan signal bahwa musik tersebut telah berfungsi sebagai media hiburan bagi masyarakat, sesuai fungsi ketiga dari fungsi musik bagi masyarakat (Merriam,1987).

\section{Penutup}

Dapat dikatakan bahwa Randai merupakan salah satu bentuk kesenian Minangkabau didukung oleh penari yang menghasilkan musik internal yang dibangun oleh penari itu sendiri, seperti tapuak galembong, suara "hep ta" atau "ais ta", tapuak paha, petik jari, tapuak tangan, hentakan kaki, dan sebagainya. Pertunjukan Randai mempunyai ciri-ciri sebagai berikut: 1) para penari bergerak dalam lingkaran besar; 2) sumber gerak penari galombang bersumber dari pencak silat; 3) karakter tokoh diungkapkan melalui akting dan dialog; 4) cerita disampaikan dalam adegan demi adegan; 5) dendang sebagai pembatas antara suatu adegan ke adegan berikutnya. Randai didukung oleh jumlah pemain antara 15 sampai 25 orang. Para pemain itu merupakan satu kesatuan kelompok pemain galombang yang menghasilkan irama bunyi tapuak galembong yang sangat atraktif dalam ceritera Randai. Akan tetapi, kesatuan kelompok itu tidak mengikat setiap individu (pemain yang lain), karena pemain bebas dalam mengikuti lingkaran galombang. Bahkan kadang-kadang seorang pemain dapat keluar dari lingkaran galombang sebelum berakhir. Ketiadaan pemain tersebut tidak mengganggu jalannya Randai yang memang tidak ada ketetapan jumlah pemain.

Ceritera yang digunakan biasanya diangkat dari $k a b a$ (cerita) yang terdapat di Minangkabau. Dalam sebuah naskah Randai terdapat dialog, suasana, tempat, adegan, dan peristiwa. Penyampaian kaba (cerita) melalui akting, dialog, dan lagu yang diiringi dengan alat-alat musik tradisional Minangkabau. Galombang untuk mengalihkan suasana dari satu adegan ke adegan berikutnya menggunakan tari, pencak, dan silat. Pengolahan gerak galombang merupakan stilasi yang halus, tetapi tetap berciri pencak silat. Hal ini kemungkinan merupakan salah satu ciri untuk membedakan gerak dalam Randai yang mempunyai kesan kekuatan (cepat, gesit, dan tangkas) dengan gerak dalam tari yang menimbulkan keindahan (lembut, halus, dan ringan). Dendang dalam Randai mempunyai fungsi sebagai irama pengatur gerak. Randai itu selalu diawali dengan Dendang Dayang Daini sebagai pembukaan dan Dendang Simarantang sebagai pengatur gerak galombang pada adegan pertama, sedangkan Dendang Palayaran untuk mengiringi gerak galombang pada adegan terakhir. Adapun adegan kedua dan selanjutnya bebas menentukan jenis dendang. Selain dendang sebagai pengatur gerak juga berfungsi untuk menyampaikan kaba (cerita).

\section{Kepustakaan}

Bahar, Mahdi. 2009. Musik Perunggu Nusantara. Perkembangan Budayanya di Minangkabau. Bandung: Sunan Ambu STSI Press.

Batubara, Junita. 2013. "Overture dalam Opera Kehidupan Dua Zaman-Hikayat Siboru Deakparujar: Penggabungan Elemen Opera Barat dan Opera Batak" dalam Resital Jurnal Seni Pertunjukan, Vol 14 No.2 Desember 2013: 93-103

Boas, Franz. 1955. Primitive Art. New York: Dover Publication.

Daruni. 2013. "Limbuk Cangik sebagai Inspirasi Perancangan Koreografi Duet Sih Biyung" dalam Resital Jurnal Seni Pertunjukan, Vol. 14 No.2 Desember 2013: 162-171.

Dewi, Maria Octavia Rosiana. 2013. "Konsep Minimax Slamet Abdul Sjukur dalam Musik "Uwek-Uwek" dalam Resital Jurnal Seni Pertunjukan, Vol. 14 No.2 Desember 2013: 104-121.

Hanefi, dkk. 2004.Talempong Minangkabau. Bandung: P4ST UPI.

Julius, Dt. Malako Nan Putiah. 2007. Mambangkik Batang Tarandam: Dalam Upaya Mewariskan dan Melestarikan Adat Minangkabau Menghadapi Modernisasi Kehidupan Bangsa. Jakarta: Citra Umbara. 
Kartomi, Margaret J. 1990. “Minangkabau Musical Culture: The Contemporary Scene and Recent Attemps at Its Modernization", dalam Glovia Davis (ed). What is Modern Indonesia Culture. Ohio: Ohio University Press. . 1990. On Concepts and Classifications of Musical Instruments. Chicago: University of Chicago Press.

Kostka, Stefan. 2006. Material and Techniques of Twentieth-Century Music. New York: Oxford University Press.

Koentjaraningrat. 1990. Pengantar Ilmu Antropologi. Jakarta: Rineka Cipta. Jakarta: UI Press.

Lee, Evert S. 1992. Teori Migrasi. Yogyakarta: Pusat Penelitian Kependudukan Universitas
Gadjah Mada.

Liliweri, Alo. 2002. Makna Budaya Dalam Komunikasi Antarbudaya. Yogyakarta: Lkis.

Martamin, Marjani. 1988. "Dendang Minangkabau” [Laporan Penelitian]. Padang Panjang: ASKI.

Merriam, Allan P. 1987. The Anthropology of Music. Chicago: North Western University Press.

Suseno, Franz Magnis. 1999. Etika Jawa Sebuah Analisis Falsafati tentang Kebijaksanaan Hidup Jawa. Jakarta: Gramedia.

Waridi. 2003. "Gending Dalam Pandangan Orang Jawa: Makna Fungsi Sosial, dan Hubungan Seni" dalam A.M. Hermien Kusmayati (ed). Kembang Setaman, Persembahan Untuk Sang Maha Guru. Yogyakarta : BP ISI Yogyakarta. 